\title{
Pengaruh Tepung Apu-apu (Pistia stratiotes) terhadap Performans dan Pendapatan Ayam Kampung Super
}

\author{
Effect of Apu-apu Flour (Pistia stratiotes) on Performance and \\ Income in of the chicken native \\ Astati \\ Jurusan Ilmu Peternakan Fakultas Sains dan Teknologi \\ Universitas Islam NegeriAlauddin, Gowa-90245 \\ Sulawesi Selatan, Indonesia \\ Korespondensi Email: astati@uin-alauddin.ac.id
}

\begin{abstract}
ABSTRAK
Penelitian ini bertujuan untuk mengetahui pengaruh level pemberian tepung apu-apu (Pistia stratiotes) terhadap performance dan nilai ekonomi ayam kampung super. Penelitian ini menggunakan rancangan acak lengkap 5 perlakuan dan 3 ulangan. Parameter dalam penelitian ini yaitu pertambahan bobot badan, konsumsi pakan, dan konversi pakan. Penelitian menggunakan ayam kampung super umur 2 bulan sebanyak 45 ekor, yang diberi pakan standar dengan penambahan tepung apu-apu (Pistia stratiotes) 5-20\% selama 4 minggu. Data dianalisis dengan menggunakan RAL (Rancangan Acak Lengkap). Hasil penelitian menunjukkan bahwa pemberian level tepung apu-apu (Pistia stratiotes) tidak berpengaruh nyata terhadap performans dan nilai IOFC ayam kampung super.
\end{abstract}

Kata kunci: Tepung apu-apu (Pistia stratiotes), performans, ayam kampung super, IOFC

\begin{abstract}
This research were aimed to determine the effect of level apu-apu flour (Pistia stratiotes) on the performance and the economic value of super native chicken. This study used a completely randomized design of 5 treatments and 3 replications. The parameters in this study are body weight gain, feed consumption, and feed conversion. This sesearch using 45 super chicken, which were given fertilization 2 month. Based on the analysis of RAL, it was shown that the level apu-apu flour (Pistia stratiotes) did not significant effect to the performance and IOFC value of super native chicken.
\end{abstract}

Key words: Pistia stratiotes, performace, super chicken, IOFC

\section{PENDAHULUAN}

Usaha peternakan ayam kampung super adalah usaha yang berpotensi untuk menghasilkan daging ayam kampung yang lebih cepat untuk memenuhi kebutuhan konsumsi bagi masyarakat. Pertumbuhan kampung super yang lebih cepat meningkat serta dapat dipanen dalam kurun waktu 3 (tiga) bulan. Keunggulan genetik ayam kampung super 
yang tumbuh lebih cepat dari ayam kampung biasa, ditambah dengan pemberian ransum yang lebih bagus yang disertai dengan pemeliharaan atau manajemen yang sesuai sehingga mampu meningkatkan pertambahan bobot badan yang lebih cepat sehingga peternak dapat memanen ayam lebih cepat untuk menghasilkan keuntungan lebih cepat.

Pakan ayam kampung super terdiri dari pakan lokal dan pakan komersil. Pakan lokal yaitu pakan yang kita olah sendiri untuk menjadi pakan ternak, dan pada penggunaan pakan lokal kita dapat menambahkan dengan daun apu-apu yang dikeringkan menjadi tepung apu-apu dan tanaman tersebut jika digunakan sebagai campuran dalam pakan diharpakan dapat memperbaiki bobot badan.

\section{METODE}

Penelitian ini menggunakan Rancangan Acak Lengkap (RAL) dengan 5 perlakuan dan 3 ulangan, perlakuan terdiri atas $\mathrm{P}_{0}$ (pakan standar), $\mathrm{P}_{1}$ (pakan standar + tepung apu-apu $5 \%), \mathrm{P}_{2}$ (pakan standar + tepung apu-apu 10\%), $\mathrm{P}_{3}$ (pakan standar + tepung apu-apu 15\%), dan $\mathrm{P}_{4}$ (pakan standar + tepung apu-apu 20\%).

Tabel 1. Pakan Standar Penelitian

\begin{tabular}{lrrrrrr}
\hline \multirow{2}{*}{ Jenis Pakan } & \multicolumn{7}{c}{ Perlakuan (\%) } \\
\cline { 2 - 8 } & $\mathrm{P}_{0}$ & $\mathrm{P} 1$ & $\mathrm{P}_{2}$ & $\mathrm{P}_{3}$ & \multicolumn{1}{c}{$\mathrm{P}_{4}$} \\
\hline Jagung & 59 & 59 & 59 & 59 & 59 \\
Dedak & 20 & 19 & 18 & 16 & 15 \\
Tepung ikan & 4 & 2 & 1 & 2 & 1 \\
Bungkil kedelai & 17 & & 5 & 10 & 15 & 20 \\
\hline
\end{tabular}

Sumber: Kandungan Nutrisi berdasarkan Hasil Penelitian, 2019.

\section{Prosedur Penelitian}

Ayam kampung super yang digunakan berumur 90-120 hari (fase finisher) sebanyak 45 ekor. Pemberian air minum secara adlibitum dan ransum setiap hari selama 4 minggu. Selama penelitian berlangsung, pengambilan data dilakukan setiap minggu dengan mengukur konsumsi pakan, PBB (Pertambahan Bobot Badan), konversi pakan dan IOFC (Income Over Feed Cost).

\section{Analisis Data}

Data yang diperoleh dianalisis dan dihitung dengan menggunakan persamaan berikut: Konsumsi Pakan $=$ Berat badan dengan pakan apu-apu - pakan sisa $\mathrm{PBB}=$ Berat badan minggu ini - berat badan minggu sebelumnya 
Konversi Pakan $=\frac{\text { Rata }- \text { rata konsumsi pakan setiap minggu }}{\text { Rata }- \text { rata pertambahan berat badan setiap minggu }}$

$\mathrm{IOFC}=(\mathrm{PBB} \times$ Harga Ayam/Kg $)-($ Konsumsi Pakan $\times$ Harga Pakan/Kg $)$

\section{HASIL DAN PEMBAHASAN}

\section{Konsumsi Pakan}

Hasil penelitian pengaruh tepung apu-apu (Pistia stratiotes) terhadap konsumsi pakan ayam kampung super selama 4 minggu disajikan pada Tabel 2.

Tabel 2. Rata-rata Konsumsi Pakan Ayam Kampung Super selama Penelitian (Gram/Ekor)

\begin{tabular}{|c|c|c|c|c|c|}
\hline \multirow{2}{*}{ Minggu } & \multicolumn{5}{|c|}{ Perlakuan } \\
\hline & $\mathrm{P}_{0}$ & $\mathrm{P}_{1}$ & $\mathrm{P}_{2}$ & $\mathrm{P}_{3}$ & $\mathrm{P}_{4}$ \\
\hline 1 & 63,0 & 47,1 & 51,3 & 49,0 & 48,3 \\
\hline 2 & 60,7 & 56,6 & 58,8 & 55,5 & 55,8 \\
\hline 3 & 69,1 & 56,1 & 63,6 & 60,5 & 60,5 \\
\hline 4 & 71,0 & 57,5 & 61,7 & 51,9 & 54,5 \\
\hline Total & 263,8 & 217,3 & 235,4 & 217,8 & 219,2 \\
\hline Rata-rata & 65,9 & 54,3 & 58,8 & 54,4 & 54,8 \\
\hline
\end{tabular}

Sumber: Hasil Analisis, 2019.

Berdasarkan hasil analisis pada Tabel 2. memperlihatkan bahwa pengaruh pemberian tepung apu-apu (Pistia stratiotes) terhadap konsumsi pakan ayam kampung super tidak berpengaruh nyata. Hal ini disebabkan tingkat palatabilitas ayam kampung super terhadap pakan yang berbentuk tepung rendah. Hal ini sesuai pendapat Murtidjo (2006), bahwa pakan yang berbentuk tepung ( $m a s h$ ) cepat diserap oleh usus, tetapi sulit dimakan karena berdebu (berbentuk tepung) sehingga ayam cenderung tidak bergairah untuk memakannya. Selain itu, rendahnya konsumsi pakan pada setiap perlakuan disebabkan juga oleh persaingan dalam memperoleh pakan. Sugiharto (2015), menjelaskan bahwa tingkah laku aganistik yang ditunjukkan oleh unggas untuk mempertahankan diri saat terjadi konflik sosial, secara umum agonistic behavior pada unggas melibatkan ancaman, agresif, penaklukan, usaha untuk menghindar, dan kapasifan (sifat apatis).

\section{Pertambahan Bobot Badan}

Hasil penelitian pengaruh tepung apu-apu (Pistia stratiotes) terhadap bobot badan ayam kampung super selama 4 minggu disajikan pada Tabel 3. 
Tabel 3. Rata-rata Pertambahan Bobot Badan Ayam Kampung Super selama Penelitian (Gram/Ekor)

\begin{tabular}{crrrrr}
\hline \multirow{2}{*}{ Minggu } & \multicolumn{6}{c}{ Perlakuan } \\
\cline { 2 - 6 } & $\mathrm{P}_{0}$ & $\mathrm{P}_{1}$ & $\mathrm{P}_{2}$ & $\mathrm{P}_{3}$ & \multicolumn{1}{c}{$\mathrm{P}_{4}$} \\
\hline 1 & 89,4 & 35,7 & 42,9 & 33,8 & 45,4 \\
2 & 94,4 & 83,2 & 53,9 & 45,7 & 63,0 \\
3 & 97,1 & 88,2 & 41,9 & 50,8 & 72,9 \\
4 & 103,7 & 51,3 & 33,1 & 63,4 & 67,1 \\
\hline Total & 384,6 & 258,4 & 171,8 & 193,7 & 248,4 \\
\hline Rata-rata & 96,15 & 64,60 & 42,95 & 48,42 & 62,10 \\
\hline
\end{tabular}

Sumber: Hasil Analisis, 2019.

Berdasarkan hasil analisis pada Tabel 3. memperlihatkan bahwa pengaruh pemberian tepung apu-apu (Pistia stratiotes) terhadap pertambahan bobot badan ayam kampung super tidak berpengaruh nyata. Rata-rata pertambahan bobot badan ayam kampong super bervariasi. Untuk pejantan saja berat tidak terlalu besar, apalagi berat betina lebih rendah lagi (Muslim, 1990). Ketidakseragaman berat ayam disebabkan antara lain oleh pemberian pakan ayam yang tidak memadai atau kurang merata dalam pemberiannya, ayam-ayam yang lebih kuat akan makan lebih dahulu dan yang lebih lemah akan makan pakan sisa atau setelah ayam yang kuat selesai makan. Hal ini sejalan dengan pendapat Handayani (2017), bahwa bobot badan dipengaruhi oleh kualitas dan kuantitas pakan yang optimal, perbedaan zat-zat makanan yang terkandung pada pakan beroengaruh pada pertambahan bobot badan yang dihasilkan.

\section{Konversi Pakan}

Hasil penelitian pengaruh tepung apu-apu (Pistia stratiotes) terhadap konversi pakan ayam kampung super selama 4 minggu disajikan pada Tabel 4. Berdasarkan hasil analisis pada Tabel 4. memperlihatkan bahwa pengaruh pemberian tepung apu-apu (Pistia stratiotes) terhadap konversi pakan ayam kampung super berpengaruh nyata. Diketahui konversi ayam kampung super selama penelitian yang tertinggi pada perlakuan P2 sebesar 1,41 dibandingkan pada perlakuan P1 sebesar 0,94, sehingga menyebabkan konversi pakan P2 lebih tinggi dari P1. Hal ini menunjukkan kandungan protein yang tinggi pada tepung apuapu (Pistia stratiotes) akan memperbesar konversi pakan ayam tersebut. Hal ini sesuai dengan pendapat nilai konversi ransum dapat dipengaruhi oleh beberapa factor diantaranya suhu lingkungan,laju perjalanan ransum melalui pencernaan, bentuk fisik, dan konsumsi ransum. 
Tabel 4. Rata-rata Konversi Pakan Ayam Kampung Super selama Penelitian (Gram/Ekor)

\begin{tabular}{|c|c|c|c|c|c|}
\hline \multirow{2}{*}{ Minggu } & \multicolumn{5}{|c|}{ Perlakuan } \\
\hline & $\mathrm{P}_{0}$ & $P_{1}$ & $\mathrm{P}_{2}$ & $\mathrm{P}_{3}$ & $\mathrm{P}_{4}$ \\
\hline 1 & 0,70 & 1,32 & 1,19 & 1,45 & 1,06 \\
\hline 2 & 0,64 & 0,68 & 1,09 & 1,21 & 0,88 \\
\hline 3 & 0,71 & 0,63 & 1,52 & 1,19 & 0,83 \\
\hline 4 & 0,68 & 1,12 & 1,86 & 0,82 & 0,81 \\
\hline Total & 2,73 & 3,75 & 5,66 & 4,67 & 3,58 \\
\hline Rata-rata & 0,68 & 0,94 & 1,41 & 1,17 & 0,89 \\
\hline
\end{tabular}

Sumber: Hasil Analisis, 2019.

\section{IOFC (Income Over Feed Cost)}

Hasil penelitian pengaruh tepung apu-apu (Pistia stratiotes) terhadap IOFC (Income Over Feed Cost) ayam kampung super selama 4 minggu disajikan pada Tabel 5.

Tabel 5. Rata-rata IOFC (Income Over Feed Cost) Ayam Kampung Super selama Penelitian $(\mathrm{Rp} / \mathrm{Kg})$

\begin{tabular}{crrrrr}
\hline \multirow{2}{*}{ Minggu } & \multicolumn{5}{c}{ Perlakuan } \\
\cline { 2 - 6 } & \multicolumn{1}{c}{$\mathrm{P}_{0}$} & \multicolumn{1}{c}{$\mathrm{P}_{1}$} & \multicolumn{1}{c}{$\mathrm{P}_{3}$} & \multicolumn{1}{c}{$\mathrm{P}_{4}$} \\
\hline 1 & 2.954 .400 & 745.320 & 1.000 .560 & 618.400 & 1.177 .460 \\
2 & 3.234 .940 & 2.789 .720 & 1.369 .060 & 1.049 .000 & 1.856 .160 \\
3 & 3.195 .520 & 3.034 .620 & 710.020 & 1.189 .700 & 2.228 .400 \\
4 & 3.468 .100 & 1.272 .600 & 334.040 & 1.952 .180 & 2.074 .600 \\
\hline Total & 12.852 .960 & 7.842 .260 & 3.413 .680 & 4.809 .280 & 7.336 .620 \\
\hline Rata-rata & 3.213 .240 & 1.960 .565 & 853.420 & 1.202 .320 & 1.834 .155 \\
\hline
\end{tabular}

Sumber: Hasil Analisis, 2019.

Berdasarkan hasil analisis padaTabel 5. memperlihatkan bahwa pengaruh pemberian tepung apu-apu (Pistia stratiotes) terhadap IOFC (Income Over Feed Cost) ayam kampung super tidak berpengaruh nyata. Hal ini disebabkan Pertambahan bobot badan yang diberikan menurun setelah masuk minggu kedua yang berarti harga pertambahan bobot badan tidak diperoleh keuntungan. Hal ini tidak sejalan pendapat Aman (2011), bahwa pemberian pakan dengan kadar gizi secukupnya (low nutrient concentration) bertujuan untuk menekan pakan sehingga biaya produksi lebih efisien dan akan mendapatkan IOFC lebih baik.

\section{KESIMPULAN}

Berdasarkan hasil dan pembahasan bahwa pemberian tepung apu-apu (Pistia stratiotes) tidak berpengaruh nyata $(\mathrm{P}>0,05)$ terhadap performance dan nilai IOFC (Income 
Over Feed Cost) ayam kampung super. Semakin tinggi konsentrasi tepung apu-apu (Pistia stratiotes) yang diberikan pada ayam kampung, maka pengaruh yang diberikan terhadap performance dan IOFC (Income Over Feed Cost) semakin rendah.

\section{DAFTAR PUSTAKA}

Aman, Y. 2011. Ayam Kampung Unggul. Penebar Swadaya, Jakarta.

Handayani, A. 2017. Penambahan tepung kunyit (Curcuma domestica) dalam ransum terhadap performans itik hibrida fase grower. Skripsi. Program Studi Peternakan Fakultas Peternakan. Universitas Nusantara PGRI, Kediri.

Muslim, D. 1990. Memelihara Ayam Kampung Sistem Battery. Kanisius, Yogyakarta.

Murtidjo, B.A. 2006. Pedoman Meramu Pakan Unggas. Kanisius, Yogyakarta.

Prayitno, D. S dan Sugiharto. 2015. Kesejahteraan dan Metode Penelitian Tingkah Laku Unggas. Badan Penerbit Universitas Diponegoro, Semarang. 